\title{
PERIODIC ANALYSIS OF MIXED VENOUS OXYGEN TENSION TO MONITOR THE ADEQUACY OF PERFUSION DURING AND AFTER CARDIOPULMONARY BYPASS
}

\author{
Theodore H. Stanley, M.D. ANd Jesus Isern-Amaral, M.D.
}

\begin{abstract}
RECENT WORK from our laboratory has demonstrated that mixed venous oxygen tension $\left(\mathrm{P}_{\bar{v}} \mathrm{O}_{2}\right)$ is a sensitive metabolic index of the adequacy of tissue blood flow after orthotopic cardiac prosthesis implantation., ${ }^{1,2}$ Experiments done in awake animals with implanted total artificial hearts have shown that $\mathrm{P}_{\bar{\gamma}} \mathrm{O}_{2}$ will indicate even a small decrease in cardiac output $(<10 \%)$ an average of seven minutes before similar changes in mixed venous oxygen saturation $\left(\mathrm{S}_{\mathrm{v}} \mathrm{O}_{2}\right)$, in oxygen content $\left(\mathrm{C} \mathrm{v}_{2}\right)$ and increases in arterial mixed venous oxygen content difference $\left(\mathrm{CaO}_{2}-\mathrm{CrO}_{2}\right)$ and 12 minutes before a change in calculated arterial base deficit. ${ }^{1}$ In this study periodic $\mathrm{PrO}_{2}$ analysis was evaluated as a method of monitoring blood flow requirements during cardiopulmonary bypass and the adequacy of postoperative perfusion in 45 patients undergoing elective aortic valve replacement or coronary artery grafting procedures.
\end{abstract}

\section{Methods}

The patients were A.S.A. Class II or III. Sixteen were scheduled for aortic valve replacement and 29 for one to three coronary artery (saphenous vein) bypass grafts. Each was premedicated with pentobarbitone (1 mg/kg), morphine (1 $\mathrm{mg} / 10 \mathrm{~kg})$ and atropine $(0.05 \mathrm{mg} / 10 \mathrm{~kg}) 90$ minutes before the operation. Before anaesthesia was begun two intravenous infusions were started in the upper extremities, a central venous pressure catheter was placed through the internal jugular vein or from the antecubital fossa and threaded to the right atrium and a radial artery catheter was inserted. A catheter was also inserted into the urinary bladder and standard electrocardiograph leads were applied to the extremities. Twelve of the 45 patients also had a Swan-Ganz catheter (Edwards Laboratories) threaded into the proximal pulmonary artery. All patients were anaesthetized with $2-3$ $\mathrm{mg} / \mathrm{kg}$ of intravenous morphine given at a rate of $5-15 \mathrm{mg} / \mathrm{min}$ plus $10-30$ per cent nitrous oxide in oxygen. Respirations were first assisted and later controlled. When the patients had become unresponsive, succinylcholine $(1.5 \mathrm{mg} / \mathrm{kg})$ was given intravenously and the trachea was intubated. Controlled ventilation was continued and paralysis was maintained with $0.5 \mathrm{mg} / \mathrm{kg}$ of d-tubocurarine given over a period of 20 minutes and $0.1 \mathrm{mg} / \mathrm{kg}$ given every hour thereafter.

From the Department of Anesthesiology and Division of Artificial Organs, the University of Utah College of Medicine, 50 North Medical Drive, Salt Lake City, Utah 84132.

This work was supported in part by The National Institutes of Health via the National Heart and Lung Institute, Grant No. 3-POL-HL-13738-02-SL and by Contract No. HT4-2905 and by the John A. Hartford Foundation, The Christina Foundation, the Lad L. and Mary Hercik Fund and Mr. Maurice Warshaw. 
Ringer's lactate in 5 per cent dextrose in water was administered at a rate of $50-70 \mathrm{ml} /$ hour during the procedures and continued postoperatively. If urine output decreased to less than $30 \mathrm{ml} /$ hour the infusion rate was increased to $200 \mathrm{ml} /$ hour. Whole blood was the only colloid given routinely during operation and during the first 24 postoperative hours. Blood was not required before bypass in any patient. During bypass, blood was added to the oxygenator as required to maintain a reservoir level adequate to allow a blood flow of at least $40 \mathrm{ml} / \mathrm{kg} / \mathrm{min}$. After bypass and in the recovery room, blood was given to maintain preoperative central venous pressure or intraoperative pulmonary wedge pressure. Urine output was measured hourly during the operation and for the first 24 postoperative hours. During bypass urine output was measured each half-hour.

The extracorporeal system (Bentley ${ }^{*}$ oxygenator, Sarnst roller pump) was primed with $20-25 \mathrm{ml} / \mathrm{kg}$ of lactated Ringer's solution. During bypass mixed venous blood samples were obtained from the common venous return line at the oxygenator every 10 minutes and analyzed simultaneously with radial arterial blood for $\mathrm{Po}_{2}, \mathrm{PCO}_{2}$ and $\mathrm{pH}$ on an Instrument Laboratories Company acid-base analyzer. Oxygen saturation ( $\mathrm{So}_{2}$ ) was determined on an American Optical Company oximeter and bicarbonate and base deficits were calculated using the Siggaard-Andersen nomogram. ${ }^{3}$ Oesophageal temperature was monitored during operation with a Yellow Springs temperature probe and recording pack (Yellow Springs Instrument Company, Yellowsprings, Ohio). All patients were cooled to a temperature of $32^{\circ} \mathrm{C}$ during extra-corporeal support and rewarmed to $37^{\circ} \mathrm{C}$ at its conclusion. Temperature corrections were made using the Hedley-Whyte nomogram for $\mathrm{Po}_{2},{ }^{4}$ the Severinghaus nomogram for $\mathrm{PCo}_{2}{ }^{5}$ and the Rosenthal correction factor for blood $\mathrm{pH}^{6}{ }^{6}$ Haemoglobin was determined spectrophotometrically every 30 minutes during bypass and every hour during the first 24 postoperative hours. Arterial and mixed venous oxygen contents were calculated from the equation:

Oxygen content $/ 100 \mathrm{ml}$ whole blood $=1.39(\mathrm{Hb})(\%$ saturation $)+0.003 \mathrm{Po}_{2}$

During cardiopulmonary bypass blood flow was maintained either at a fixed rate of $40-60 \mathrm{ml} / \mathrm{kg} / \mathrm{min}$. (Group 1), controlled to keep $\mathrm{SvO}_{2}$ at 73-77 per cent (Group 2) or was controlled to maintain $\mathrm{P}_{\bar{v}} \mathrm{O}_{2}$ at $38-42$ torr (Group 3). Gas flow into the oxygenator consisted of oxygen (97-99 per cent) plus carbon dioxide ( $1-3$ per cent) and was regulated to maintain arterial $\mathrm{Po}_{2}$ between $150-200$ torr and $\mathrm{PCO}_{2}$ between 34-42 torr. Base deficits greater than $4 \mathrm{mEq} / \mathrm{L}$ were half corrected with sodium bicarbonate every 10 minutes. The lungs of patients with Swan-Ganz catheters in place were ventilated postoperatively with volumes of 7 to $15 \mathrm{ml} / \mathrm{kg} /$ breath on a pressure limited respirator in order to maintain arterial $\mathrm{PCO}_{2}$ at 35-40 torr. Postoperative inspired oxygen concentrations were adjusted to maintain the arterial $\mathrm{Po}_{2}$ between 125-175 torr. In addition, this group of patients had arterial and mixed venous blood samples drawn and analyzed as during bypass, every 10 minutes for the first 2 to 4 postoperative hours and every hour thereafter for the next 20 hours.

'Bentley Laboratories, Inc., Irvine, California.

† Sarns Incorporated, Ann Arbor, Michigan. 


\section{Results}

Fourteen of the 45 patients studied were in Group 1, 15 in Group 2 and 16 in Group 3. Mean preoperative data of the three groups were similar (Table I). Haemoglobin of the 3 groups was similar during bypass and averaged $8.1 \mathrm{gm}$. In spite of similar mean arterial blood pressures, flows, blood loss and replacement and duration of bypass, patients in Groups 2 and 3 had significantly less sodium bicarbonate requirements and greater urine outputs during bypass than those in Group 1 ( Table II). Group 3 patients also had a significantly greater urine output than those in Group 2. However, sodium bicarbonate requirements of the two groups were not statistically different. Normal $\mathrm{pH}$ values (assumed to be $7.40 \pm$ 0.03 ) were obtained during bypass in 84 per cent (134 of 160) of the measurements in Group 3 but in only 41 per cent ( 62 of 151) and 63 per cent (100 of 159) of those in Groups 1 and 2 respectively (Figure 1). The differences between Group 1 and Groups 2 and 3 were significant using the rank and sum test at the 1 per cent level; but that between Groups 2 and 3 was only significant at the 5 per cent level.

The 12 patients with Swan-Ganz catheters were equally divided between the three groups. Postoperative haemoglobin levels of all were maintained between 11 and 13 gm per cent during the first 24 postoperative hours. Four of these patients (two in Group 1 and one each in Groups 2 and 3) had evidence of low cardiac output (increased arterial-venous oxygen content difference, urine output $<20$ $\mathrm{ml} /$ hour and an arterial blood pressure drop of 20 per cent to 25 per cent or more as compared with end-operative controls) during the first four postoperative hours.

TABLE I

Mean Preoperative Data

\begin{tabular}{lccccc}
\hline & Group & $\begin{array}{c}\text { Number of } \\
\text { Patients }\end{array}$ & Age (Vears) & Weight $(\mathrm{Kg})$ & $\begin{array}{c}\text { Cardiac } \\
\text { Output L/min }\end{array}$ \\
\cline { 1 - 4 } Mean & 1 & 14 & 48 & 76 & 4.6 \\
S.D. & 2 & 15 & 7.1 & 11 & 1.3 \\
Mean & 2 & & 49 & 77 & 4.9 \\
S.D. & 3 & 16 & 7.0 & 6.4 & 1.0 \\
Mean & & & 7.3 & 77 & 4.8 \\
S.D. & & & 7.9 & 0.9 \\
\hline
\end{tabular}

TABLE II

Mean Bypass Data

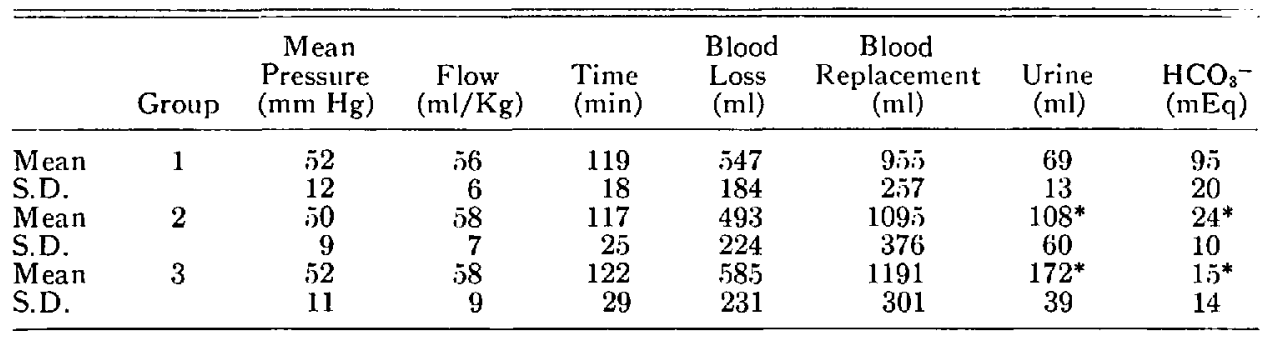

\footnotetext{
*P $<0.01$, Students $\mathrm{T}$-test when compared to Group 1 values.
} 


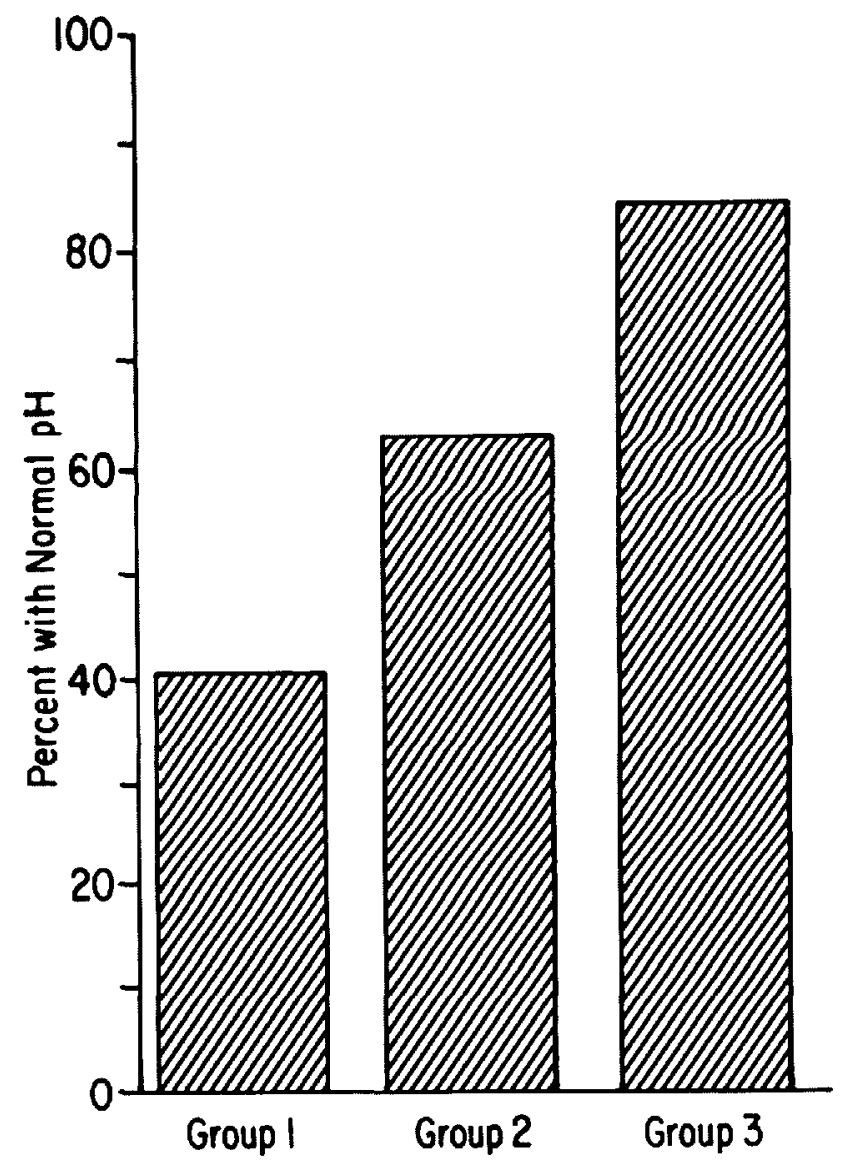

Figure 1. A graph of the percentage of normal blood pH measurements during cardiopulnonary bypass in patients with bypass flows maintained at $40-60 \mathrm{ml} / \mathrm{kg} / \mathrm{hr}$ (Group l), patients with bypass flows controlled to keep $\mathrm{SvO}_{3}$ at 73-77 per cent (Group 2) and patients with bypass flows controlled to maintain $\mathrm{P}_{\bar{v}} \mathrm{O}_{2,}$ at $38-42$ torr (Group 3 ).

In these four patients decreases in systolic arterial pressure of $20 \mathrm{~mm} \mathrm{Hg}$ from end-operative levels only occurred after $\mathrm{S}_{\bar{v}} \mathrm{O}_{2}$ had dropped to 65 per cent or less for an average of 23 minutes and $\mathrm{P}_{\bar{v}} \mathrm{O}_{2}$ had diminished to 32 torr or less for a mean of 26 minutes. Use of a variety of positive inotropic cardiac drugs restored $\mathrm{Pv}_{2}$ and $\mathrm{S}_{\bar{v}} \mathrm{O}_{2}$ to levels above 32 torr and 65 per cent saturation respectively and systolic arterial blood pressure to end-operative levels in equal time periods in each of the patients. The other eight patients had postoperative $\mathrm{PvO}_{2}$ and $\mathrm{SvO}_{2}$ values which were consistently above 32 torr and 65 per cent saturation. The latter also had no evidence of a significant decrease in cardiac output from end-operative levels at any time during their first 24 postoperative hours.

\section{Discussion}

Previous reports by a number of authors have shown that central venous or mixed venous oxygen saturation monitoring is an effective means of detecting less than 
adequate perfusion states before cardiovascular collapse occurs and often before cardiovascular haemodynamics change. ${ }^{7-9}$ Goldman, Klughaupt, Metcalf, Spivak and Harrison ${ }^{8}$ found that by monitoring $\mathrm{S}_{\overline{0}} \mathrm{O}_{2}$ they could often predict deterioration or improvement in patients with myocardial infarction before it was clinically evident. Martin, Cheung, Johnson and Wong' showed that $\mathrm{S}_{\bar{v}} \mathrm{O}_{2}$ remained $>60$ per cent over 98 per cent of the time in healthy patients undergoing operative procedures but was very unstable (varying between 35 and 70 per cent) in those with significant cardiac disease. In three patients in the latter group a rapidly falling $\mathrm{S}_{\bar{v}} \mathrm{O}_{2}$ preceded signs of inadequate perfusion and cardiac arrest by 2 to 10 minutes. Our study confirms the findings of these authors but suggests that periodic measurements of mixed venous oxygen tension $\left(\mathrm{P}_{\bar{v}} \mathrm{O}_{2}\right)$ may be superior to measurement of $\mathrm{S}_{\bar{v}} \mathrm{O}_{2}$ in predicting the adequacy of perfusion during and after cardiopulmonary bypass. Bypass flow rates regulated to maintain $\mathrm{P}_{\bar{v}} \mathrm{O}_{2}$ at normal levels (corrected for temperature change to $37^{\circ} \mathrm{C}$ ) resulted in lower sodium bicarbonate requirements and higher urine outputs than when flow rates were regulated to maintain normal oxygen saturations. While the difference in sodium bicarbonate requirements between the two groups was not quite statistically significant $(P>0.05)$ the urine output difference was very significant $(P<0.01)$. Blood $\mathrm{pH}$ values during bypass were also more frequently within normal limits when bypass flows were regulated by $\mathrm{P}_{\bar{v}} \mathrm{O}_{2}$ rather than by $\mathrm{S}_{\bar{v}} \mathrm{O}_{2}$.

That $\mathrm{P}_{\bar{v}} \mathrm{O}_{2}$ analysis should be more sensitive than $\mathrm{S}_{\bar{v}} \mathrm{O}_{2}$ in predicting perfusion requirements is easy to understand if it is realized that tissue needs for oxygen are reflected in decreases of partial pressure of oxygen in tissues and result in oxygen tension gradients between capillaries feeding the tissues and the tissues themselves. Oxygen is unloaded from haemoglobin only after that which is physically dissolved in blood is partially removed. Thus changes in blood oxygen tension must occur before changes in oxygen saturation of haemoglobin and measurements of oxygen saturation and analysis or calculations based on oxygen saturation (oxygen content) must be less sensitive (i.e. must take longer to reflect tissue oxygen requirements) than oxygen tension measurements. In addition, $\mathrm{P}_{\bar{v}} \mathrm{O}_{2}$ must be more accurate than $\mathrm{SvO}_{2}$ as a measure of the adequacy of tissue perfusion as the former is not affected by changes in haemoglobin concentration or the oxygenhaemoglobin saturation curve, by a change in blood $\mathrm{pH}$ or the use of old blood, as the latter is. $\mathrm{P}_{\bar{v}} \mathrm{O}_{2}$ is also unaffected by changes in acid-base balance that arise because of alterations other than those due to tissue perfusion, such as metabolic alkalosis resulting from hepatic metabolism of citrate after massive blood replacement or from prolonged periods of vomiting or gastric suction.

It might argued that, if it were possible, the best method of monitoring the adequacy of tissue perfusion in patients with marginal myocardial reserve and not on bypass would be to continuously measure cardiac output. Experiments in our laboratory in animals with artificial hearts suggest that the above is not true.,2,11 The reason is that cardiac output reflects only the ability of the heart and vascular system to move a certain volume of blood in a given time period and does not take into consideration the adequacy of that pumped blood to meet tissue metabolic needs. In animals who cannot increase cardiac output but yet sustain increases in tissue oxygen requirements, as from a rise in body temperature or shivering, moni- 
toring of cardiac output will detect an unchanged cardiac output but not an imbalance of oxygen requirements and supply. However, $\mathrm{P}_{\bar{v}} \mathrm{O}_{2}$, or $\mathrm{S}_{\bar{v}} \mathrm{O}_{2}$ monitoring quickly reveals such imbalances and allows treatment to be initiated earlier, before dangerous degrees of anerobic metabolism and metabolic acidosis occur.

While this study was accomplished using intermittent sampling of mixed venous blood, it is obvious that continuous $\mathrm{P}_{\bar{v}} \mathrm{O}_{2}$ monitoring would be more desirable. Unfortunately, a reliable device for continuous $\mathrm{P}_{\bar{v}} \mathrm{O}_{2}$ monitoring during and after bypass is not presently available. Continuous monitoring of $\mathrm{S}_{\bar{v}} \mathrm{O}_{2}$ is now possible with a commercially available fiberoptic in vivo oximeter which is an adaptation of a previously described University of Washington oximeter. ${ }^{10}$ Martin et al. $^{{ }^{\mathrm{B}}}$ have reported reliable continuous measurements of $\mathrm{S}_{\bar{v}} \mathrm{O}_{2}$ with the latter device. Our results in this study suggest that until continuous $\mathrm{P}_{\bar{v}} \mathrm{O} .2$ monitoring becomes available, monitoring of blood flow requirements during and after cardiopulmonary bypass can be best achieved by continuous measurements of $\mathrm{S}_{\bar{v}} \mathrm{O}_{2}$ associated with intermittent measurements of $\mathrm{P}_{\bar{v}} \mathrm{O}_{2}$.

\section{SUMMARY}

Periodic $\mathrm{P}_{\bar{v}} \mathrm{O}_{2}$ analysis was evaluated with periodic $\mathrm{S}_{\bar{v}} \mathrm{O}_{2}$ analysis and compared with the standard technique of maintaining blood flow at a rate of $40-60$ $\mathrm{ml} / \mathrm{kg} / \mathrm{min}$, as methods of regulating blood flow during cardiopulmonary bypass. Both analytical methods resulted in significantly smaller sodium bicarbonate requirements, greater urine outputs and blood $\mathrm{pH}$ that was more frequently normal during cardiopulmonary bypass than those values obtained when a fixed flow rate was maintained. Periodic $\mathrm{P}_{\bar{v}} \mathrm{O}$. $\mathrm{S} \overline{\mathrm{v}} \mathrm{O}$.2 monitoring during bypass in that urine output and blood $\mathrm{pH}$ were better with the former than with the latter. Postoperatively, however, both methods were equally good in predicting inadequate total blood flows. These findings suggest that periodic $\mathrm{P} \overline{\mathrm{v}} \mathrm{O}_{2}$ analysis is superior as a method of controlling bypass blood flow rates and as a sensitive means of monitoring the adequacy of postoperative cardiac output to meet tissue metabolic needs.

\section{RÉSUMÉ}

Nous avons étudié la tension d'oxygène du sang veineux central $\left(\mathrm{P}_{\bar{v}} \mathrm{O}_{2}\right)$ de même que la saturation en oxygène du sang veineux $\left(\mathrm{S}_{\bar{v}} \mathrm{O}_{2}\right)$, comme méthode de monitoring des besoins en débit sanguin durant et après la circulation extra-corporelle, ceci chez 45 malades opérés pour chirurgie coronarienne ou remplacement valvulaire aortiqus. Durant la C.E.C. le sang pour la ( $\left.\mathrm{P}_{\bar{v}} \mathrm{O}_{2}\right)$ était prélevé de la ligne veineuse de l'oxygénateur; après la C.E.C., les prélèvements furent faits par un cathéter placé dans l'artère pulmonaire. Le débit de la pompe fut, soit maintenu à un chiffre fixe (Groupe 1), soit contrôlé de façon à garder la $\mathrm{S}_{\bar{v}} \mathrm{O}_{2}$ entre 73 et 77 pour cent, (groupe 2 ) ou maintenu à un débit suffisant pour obtenir une $\mathrm{P}_{\mathrm{v}} \mathrm{O}$. entre 38 et 42 torr (groupe 3 ). Des prélèvements artériels furent faits simultanément aux analyses du sang veineux, ceci à toutes les 10 minutes durant les 4 premières heures post-opératoires. Un déficit en base de plus en plus de $4 \mathrm{mEq} / \mathrm{l}$ fut à demi corrigé à l'aide de bicarbonate de sodium. 
Des valeurs normales de $\mathrm{pH}(7.40 \pm 0.03)$ furent obtenues durant la C.E.C. dans 84 pour cent des analyses faites chez les malades du groupe 3 , mais seulement chez 41 et 63 pour cent des patients des groupes 1 et 2 respectivement.

Les débits urinaires étaient supérieurs de façon significative, et les besoins en bicarbonates significativement inférieurs chez les malades des groupes 2 et 3.

Quatre patients qui avaient des signes de bas débit cardiaque en post-opératoire avaient des saturations veineuses à 65 pour cent ou moins et des $\mathrm{P}_{\bar{v}} \mathrm{O}_{2}$ à 32 ou moins, 20 minutes au moins avant une chute de tension artérielle (de $20 \mathrm{~mm}$ ou plus). Ces chiffres suggèrent que l'analyse périodique de la $\mathrm{P}_{\bar{v}} \mathrm{O}_{2}$ est une méthode supérieure pour contrôler le débit de la C.E.C. et un moyen sensible de surveiller si le débit cardiaque post-opératoire répond aux besoins métaboliques.

\section{REFERENCES}

1. Stanley, T.H., Voldeh, J., \& KolfF, W.J. Extrinsic artificial heart control via mixed venous blood gas tension analysis. Trans. Amer. Soc. Artif. Int. Organs 19: 258 (1973).

2. Stanley, T.H. \& KolfF, W.J. Metabolic monitoring and control of the artificial heart. J. Thoracic and Cardiovas. Surg. 67: 434 (1974).

3. Siggahd-Andersen, O. \& Engel, K. A new acid-base normogram. Scand. J. Clin. Lab. Invest. 12: 177 (1960).

4. Hedley-Whyte, J., Radfond, E.P., \& Laver, M.B. Normogram for temperature correction or electrode calibration during $\mathrm{Po}_{2}$ measurements. J. Appl. Physiol. 20: 785 (1965).

5. Severinchaus, J.W. Blood gas concentrations: Handbook of Physiology. Section 3, Respiration, Vol. 2, 1475 ( 1965 ).

6. Rosenthal, T.B. The effect of temperature on the $\mathrm{pH}$ of blood and plasma in vitro. J. Biol. Chem. 173: 25 (1948).

7. Hutrer, A.M. \& Moss, A.J. Central venous oxygen saturations. Value of serial determinations in patients with acute myocardial infarction. J.A.M.A. 212: 299 (1970).

8. Goldman, R.H., Klughaupt, M., Metcalf, T., Spivak, A.P., \& Harrison, D.C. Measurement of central venous oxygen saturation in patients with myocardial infarction. Circulation 38: 941 ( 1968).

9. Martin, W.E., Cheung, P.W., Johnson, C.C., \& Wong, K.C. Continuous monitoring of mixed venous oxygen saturation in man. Anesth. and Analg. 52: 784 (1973).

10. Cole, J.S., Martin, W.E., Cheunc, P.W., \& Johnson, C.C. Clinical studies with a solid state fiberoptic oximeter. Am. J. Cardiol, 29: 383 (1972).

11. Stanley, T.H. (unpublished data). 